\title{
Expression of an extremely acidic $\beta$-1,4-glucanase from thermoacidophilic Alicyclobacillus sp. A4 in Pichia pastoris is improved by truncating the gene sequence
}

Yingguo Bai ${ }^{1}{ }^{2}$, Jianshe Wang ${ }^{1}$, Zhifang Zhang' ${ }^{2}$ Pengjun Shi', Huiying Luo' ${ }^{1}$ Huoqing Huang ${ }^{1}$, Chunliang Luo ${ }^{1}$ and Bin $\mathrm{YaO}^{* 1}$

\begin{abstract}
Background: Alicyclobacillus sp. A4 is thermoacidophilic and produces many glycoside hydrolases. An extremely acidic $\beta$-1,4-glucanase (CelA4) has been isolated from Alicyclobacillus sp. A4 and purified. This glucanase with a molecular mass of $48.6 \mathrm{kDa}$ decreases the viscosity of barley-soybean feed under simulated gastric conditions. Therefore, it has the potential to improve the nutrient bioavailability of pig feed. For the study reported herein, the full-length gene, CelA4, of this glucanase (CelA4) was identified using the sequences of six peptides and cloned from strain A4. The gene fragment $\left(C e / A 4_{F}\right)$ encoding the mature protein was expressed in Pichia pastoris. Sequence truncation and glycosylation were found for recombinant CelA4 $F_{F}$, both of which affected the expression efficiency. The physical properties of various forms of CelA4 as they affected enzymatic activity were characterized.

Results: We located the full-length 2,148-bp gene for CelA4 (CelA4) in the genome of Alicyclobacillus sp. A4. CelA4 encodes a 715-residue polypeptide with a calculated molecular mass of $71.64 \mathrm{kDa}$, including an N-terminal signal peptide (residues 1-39), a catalytic domain (residues 39-497), and a C-terminal threonine-rich region (residues 498-715). Its deduced amino acid sequence and that of an Alicyclobacillus acidocaldarius endo- $\beta-1,4-$ glucanase were identical at $44 \%$ of the residue positions. When the experimental molecular mass of CelA4 ${ }_{F}^{--a}$ recombinant protein designed to mimic the CelA4 sequence lacking the N-terminal signal peptide that had been expressed in Pichia pastoris--was compared with its hypothetical molecular mass, it was apparent that CelA4 $4_{F}$ was truncated, possibly at residue 497. An artificially truncated gene fragment (CelA4 $)$ without C-terminal threonine-rich region was expressed in P. pastoris, and the expression efficiency of CelA4 $4_{T}$ was substantially greater than that of CelA4 $4_{F}$. Purified CelA4 $4_{F}$ and CelA4 $4_{T}$ had similar molecular masses ( $\sim 60 \mathrm{kDa}$ ) and enzymatic properties (optimum pH, 3.4; optimum temperature, $60^{\circ} \mathrm{C}$ ); they were relatively stable between $\mathrm{pH} 1.2$ and 8.2 at $70^{\circ} \mathrm{C}$ and resistant to acidic and neutral proteases. However, their molecular masses and thermostabilities differed from those of CelA4 isolated from Alicyclobacillus sp. A4. A deglycosylated form of CelA4 (CelA4 ) had properties similar to that of CelA4 except that it was thermoliable at $60^{\circ} \mathrm{C}$.

Conclusions: Truncation during expression of CelA4 $A_{F}$ or artificial truncation of its gene--both of which produced a form of CelA4 lacking a threonine-rich region that includes a putative linker--increased the level of enzyme produced in comparison with that produced by cultivation of Alicyclobacillus sp. A4. Glycosylation increased the thermostability of CelA4. Of the four forms of CelA4 studied, CelA4 4 was produced in highest yield and had the most favorable physical properties; therefore, it has potential for use in the feed industry.
\end{abstract}

\section{Background}

$\beta$-Glucan is the major cell-wall component of cereals such as barley, wheat, oat, and rye [1], and it can be

*Correspondence: yaobin@caas-bio.net.cn

${ }^{1}$ Key Laboratory for Feed Biotechnology of the Ministry of Agriculture, Feed Research Institute, Chinese Academy of Agricultural Sciences, Beijing 100081, PR China Full list of author information is available at the end of the article

(c) 2010 Bai et al; licensee BioMed Central Ltd. This is an Open Access article distributed under the terms of the Creative Commons AtB. Wed Central tribution License (http://creativecommons.org/licenses/by/2.0), which permits unrestricted use, distribution, and reproduction in any medium, provided the original work is properly cited. hydrolyzed by $\beta$-glucanases. Microbial glucanases are often used in industry, including those related to waste management [2], alcohol fermentation [3], and animal feed production [4]. Several $\beta$-glucanases from the genus Alicyclobacillus have been identified, including two endoglucanases (CelA and CelB) [5,6], one $\beta$-1,4-glucanase 
(CelA4) [7], one $\beta$-1,3(4)-glucanase (Agl9A) [8], and one cellulase (CelG) [9]. All are very thermoacidophilic and have optimum activities between 45 and $60^{\circ} \mathrm{C}$ and $\mathrm{pH} 2.0$ and 6.0.

According to the primary structures of their catalytic domains, $\beta$-1,4-glucanases have been classified as members of the glycoside hydrolase (GH) families 5, 6, 7, 8, 9, $12,44,45,48$, and 51 http://www.cazy.org/fam/ acc GH.html. Most of the GH 51-type glucanases are $\alpha$ L-arabinofuranosidases. Only three $\beta$-glucanases, endoglucanase F precursor from Fibrobacter succinogenes (AAC45377) [10], endoglucanase CelB from A acidocaldarius (CAD86595) [6], and a cellulase from an uncultured bacterium (CAF22222.1) [11], are GH 51-type glucanases.

We previously purified the extremely acidic GH 51type $\beta$-1,4-glucanase, CelA4 with a molecular mass of $48.6 \mathrm{kDa}$, from the thermoacidophilic Alicyclobacillus sp. A4 [7]. The pH optimum of CelA4 is 2.6 , it is protease resistant, and can decrease the viscosity of barley-soybean feed under simulated gastric conditions. These properties indicate that CelA4 may improve the nutrient bioavailability of pig feed. For the commercialization of CelA4, recombinant gene expression in a high-throughput fermentation system is necessary. The methylotrophic yeast, Pichia pastoris, is an excellent host for the heterologous expression of recombinant proteins for which expression is controlled by the alcohol oxidase 1 promoter [12]. High-cell-density fed-batch cultivation usually consists of four phases and has been widely used to improve protein expression in $P$. pastoris [13]. The purpose of the study reported herein was to obtain the gene for CelA4 and, using it, to develop a high-yield fermentation process for CelA4 in P. pastoris. Upon doing so, we then examined how the physical properties of the native and recombinant enzymes affected enzymatic activity and identified certain properties that affected expression efficiency.

\section{Results \\ Identification and sequence analysis of the full-length $\beta$ - 1,4-glucanase gene (CelA4)}

We located the 2,148-bp full-length $\beta$-1,4-glucanase gene (Figure 1) (CelA4) in the Alicyclobacillus sp. A4 genome using six known peptide sequences of CelA4 as identifiers [7]. CelA4 encodes a 715-residue polypeptide (calculated molecular mass, $71.64 \mathrm{kDa}$ ), which includes an N-terminal signal peptide (residues 1-39), a catalytic domain (residues 39-497), and a C-terminal threonine-rich region (residues 498-715, 21.12\% threonine). Pro, Asp, Ser, and Glu--typical linker amino acids [14]--comprise 62\% of residues 498-523, and therefore this region is presumed to be a linker. The enzyme also contains nine putative Nglycosylation sites having the consensus sequence, Asn-
Xaa-Thr/Ser-Zaa, where Zaa is not Pro; five of these sequences are in the catalytic region, and four are in the threonine-rich region. The deduced amino acid sequence of CelA4 is most similar (44\% identical) to that of the $\mathrm{GH}$ 51 cellulase, CelB, from $A$. acidocaldarius (CAD86595) [6]. The threonine-rich regions of these two enzymes have only $28 \%$ of their residues in common, and the threonine-rich region of CelA 4 has $<15 \%$ sequence identity with those of other glucanases. Alignment of CelA4 with five other glucanases using ClustalW is shown in Figure 2. The sequence alignment indicated that CelA4 does not contain a carbohydrate (cellulose)-binding domain found in the four glucanase sequences of ACU75486 (residues 625-724), EEP70239 (residues 600-699), ACU35994 (residues 575-676), and EEW74700 (residues 613-716). The putative catalytic residue in CelA4, Glu176, is highly conserved in glucanases and is located within the active site as predicted by sequence alignment $[15,16]$.

\section{Expression and purification of recombinant CelA4 $4_{F}$ in $P$. \\ pastoris}

The gene $\left(\mathrm{CelA} 4_{F}\right)$, which encodes a form of CelA4 that lacks the $\mathrm{N}$-terminal signal sequence, was cloned into the pPIC9 vector that was then transformed into P. pastoris competent cells. The cells were cultured and clones were isolated. The clone that had the highest $\beta$-1,4-glucanase activity after flask cultivation was selected for expression in a 3.7-L fermenter. During fermentation, the cell mass of recombinant $P$. pastoris kept increasing from phase one $(\sim 110 \mathrm{~g} / \mathrm{L}$; about 18 hours $)$ to phase four $(\sim 350 \mathrm{~g} / \mathrm{L}$; about 184 hours) (Figure 3) (See Methods for descriptions of the cultivation phases). The $\beta$-1,4-glucanase activity in the supernatant was $268 \mathrm{U} / \mathrm{mL} 156 \mathrm{~h}$ after induction with methanol.

Recombinant CelA4 $4_{F}$ was purified by anion exchange chromatography. It migrated as a single band upon SDSPAGE and had an apparent molecular mass of $\sim 60 \mathrm{kDa}$ (Figure 4), which is less than the predicted molecular mass $(71.64 \mathrm{kDa})$ of CelA $4_{\mathrm{F}}$, but greater than that of CelA4 (48.6 kDa). Using LC-ESI-MS/MS, this band was identified as CelA4 $4_{\mathrm{F}}$. These results indicate that recombinant CelA4 $4_{F}$ was probably both truncated and glycosylated.

\section{Deglycosylation and artificial truncation of CelA4 ${ }_{F}$}

Because CelA4 has nine putative $\mathrm{N}$-glycosylation sites, the observed variation in apparent molecular mass of CelA4 ${ }_{F}$ might be ascribed to glycosylation and/or truncation. After endo- $\beta-N$-acetylglucosaminidase $\mathrm{H}$ (Endo $\mathrm{H}$ ) treatment, the protein migrated as a single band of 48 $\mathrm{kDa}$ upon SDS-PAGE, and thus the decrease in apparent molecular mass was ascribed to deglycosylation. The molecular mass of deglycosylated $\mathrm{CelA}_{\mathrm{F}}\left(\mathrm{CelA} 4_{\mathrm{D}}\right)$ is 


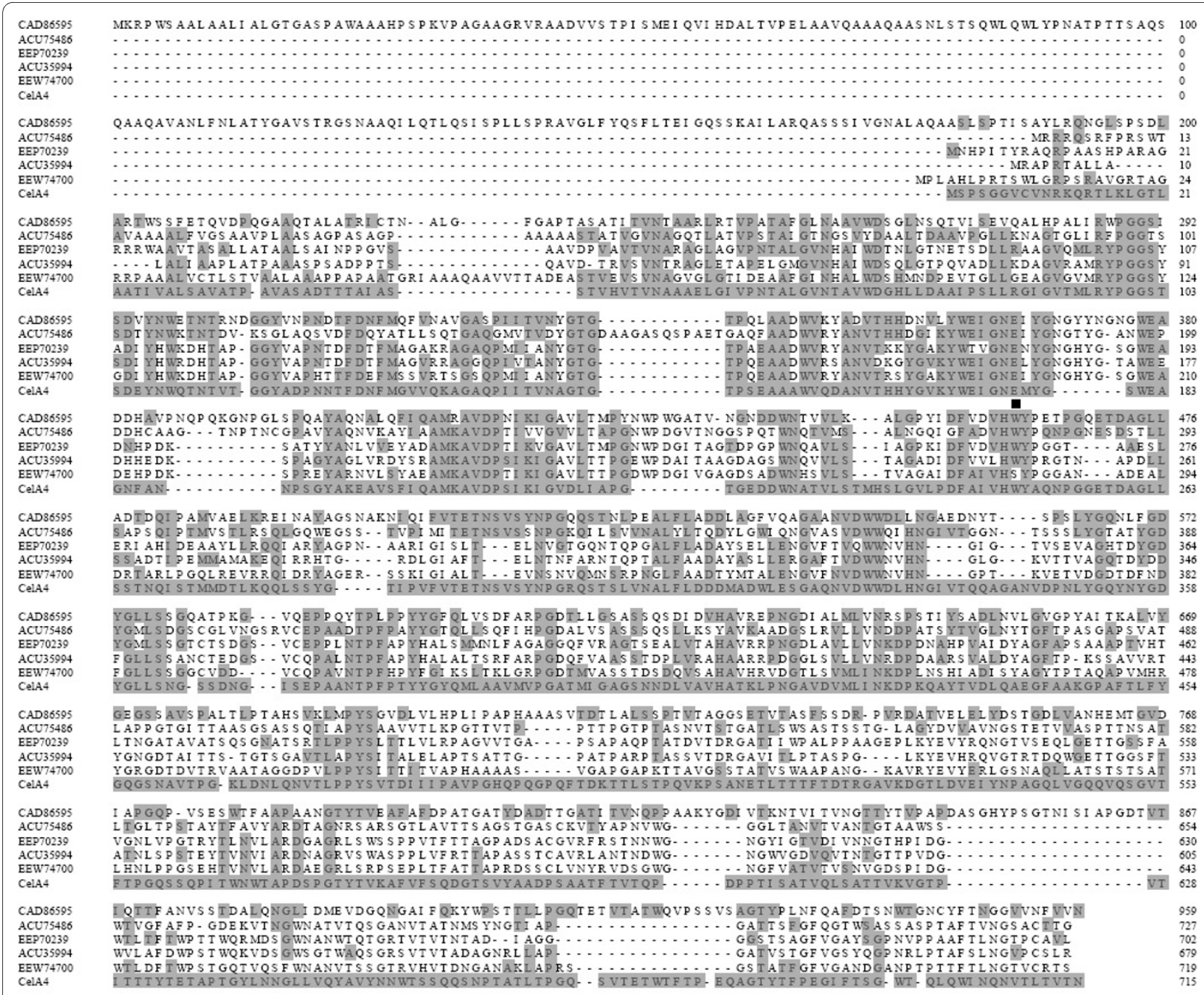

Figure 2 Amino acid sequence alignment of CelA4 $4_{\mathrm{F}}$ and five other glucanases. The sequences were those of glucanases from Alicyclobacillus acidocaldarius DSM 446 (CAD86595), Catenulispora acidiphila DSM 44928 (ACU75486), Micromonospora sp. ATCC 39149 (EEP70239), Actinosynnema mirum DSM 43827 (ACU35994), and Streptomyces flavogriseus ATCC 33331 (EEW74700). ClustalW was used to align the sequences. Residues that are the same at all positions are indicated by solid grey boxes; the catalytic residue, Glu176, is indicated by a solid square.

almost the same as that of CelA4. Therefore, CelA4 $4_{\mathrm{F}}$ was both glycosylated and truncated when expressed in $P$. pastoris.

According to the molecular mass comparison and sequence analysis, residue 497 was predicted to be the truncation site. CelA4 $4_{\mathrm{T}}$ was expressed in P. pastoris as described above. The $P$. pastoris culture for CelA $4_{\mathrm{T}}$ followed the same growth profile as for CelA4 $4_{F}$. The $\beta-1,4-$ glucanase activity in the supernatant of the CelA4 $4_{\mathrm{T}}$ culture reached $420 \mathrm{U} / \mathrm{mL}$ (Figure 3), which was much higher than that found for the CelA4 $4_{\mathrm{F}}$ culture. Purified CelA $4_{\mathrm{T}}$ migrated as a single band upon SDS-PAGE and had a molecular mass of $\sim 60 \mathrm{kDa}$, which is the same as found for CelA4 $4_{\mathrm{F}}$.

\section{Enzyme characterization}

The physical properties of truncated CelA4 $4_{\mathrm{F}}$, artificially truncated CelA4 $4_{\mathrm{T}}$, deglycosylated and truncated CelA4 ${ }_{\mathrm{D}}$, and CelA4 [7] that affect enzyme activity were characterized and compared. CelA4 $4_{\mathrm{F}}, \mathrm{CelA} 4_{\mathrm{T}}$, and CelA4 $4_{\mathrm{D}}$ showed optimum activity at $\mathrm{pH} 3.4$, as opposed to $\mathrm{pH} 2.6$ for native CelA4. The first three enzymes were less active between $\mathrm{pH} 1.2$ and 2.2 and between 4.8 and 7.6 than was native CelA4 (Figure 5A). CelA4 $4_{\mathrm{F}}, \mathrm{CelA} 4_{\mathrm{T}}, \mathrm{CelA} 4_{\mathrm{D}}$, and CelA4 were all stable between $\mathrm{pH} 1.8$ and 8.2 , at $37^{\circ} \mathrm{C}$ for $1 \mathrm{~h}$, but the first three enzymes were more stable at $\mathrm{pH}$ 1.2 ( $>70 \%$ retention of activity) than was CelA4 ( $36 \%$ retention of activity) (Figure $5 \mathrm{~B}$ ). All of the enzymes displayed maximum activity between 60 and $65^{\circ} \mathrm{C}$ (Figure 5C). Notably, CelA $4_{\mathrm{F}}$ and CelA4 $4_{\mathrm{T}}$ were relatively stable at 


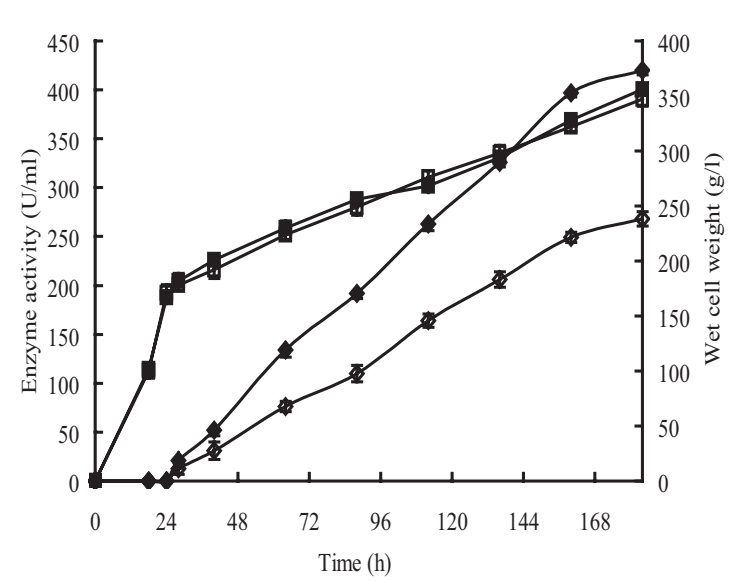

Figure 3 Time courses for the appearance of $\beta$-1,4-glucanase activity and increase in biomass during fermentation. The symbols and associated proteins are as follows: diamond stands for activity; Square stands for biomass; hollow stands for CelA4 $4_{F}$ and solid stands for CelA4.

$75^{\circ} \mathrm{C}$, as they maintained $>75 \%$ of their initial activities after a 1 -h incubation at $\mathrm{pH} 3.4,75^{\circ} \mathrm{C}$. Under the same conditions, CelA4 ${ }_{D}$ and CelA4 lost all activity (Figure 5D).

CelA $4_{\mathrm{F}}, \mathrm{CelA} 4_{\mathrm{T}}$, and $\mathrm{CelA} 4_{\mathrm{D}}$ were highly resistant to the acidic and neutral proteases, including trypsin, $\alpha$-chymotrypsin, collagenase, pepsin, and subtilisin A, and they retained more than $70 \%$ of their activities after incubation with these proteases at $37^{\circ} \mathrm{C}$ for $2 \mathrm{~h}$. This resistance to

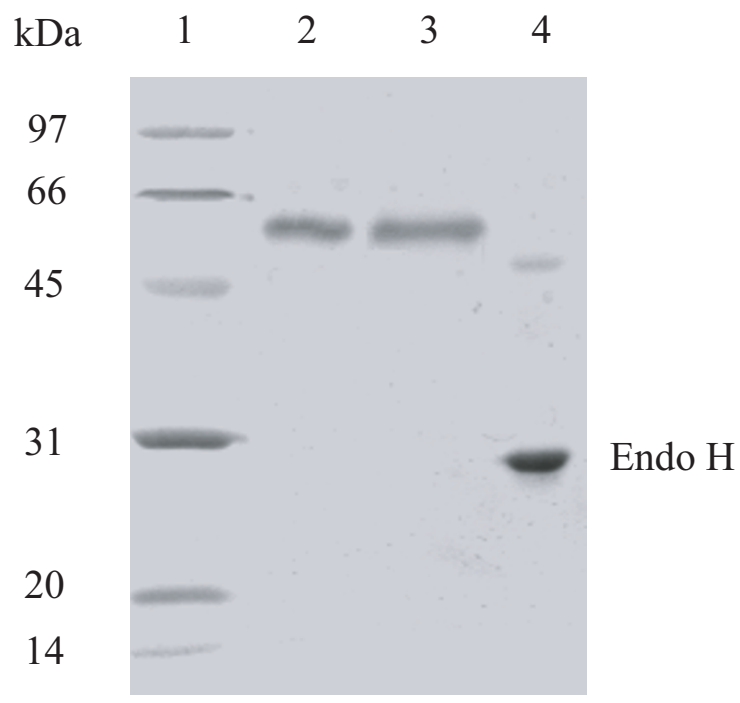

Figure 4 SDS-PAGE gels of purified CelA4 ${ }_{\mathrm{F}}$ and $\mathrm{CelA}_{\mathrm{T}}$ before and after Endo $\mathrm{H}$ treatment. Lanes: 1, standard protein molecular-weight markers; 2 , purified CelA4 4 ; 3 , purified CelA4 $4_{F}$ 4, purified CelA4 $4_{F}$ after deglycosylation with Endo $\mathrm{H}$. acidic and neutral proteolysis had been found previously for CelA4 [7].

\section{Nucleotide sequence accession number}

The nucleotide sequence of the $\beta$-1,4-glucanase gene (CelA4) from Alicyclobacillus sp. A4 was deposited in GenBank under the accession number GU576556.

\section{Discussion}

We previously isolated an extremely acidic GH $51 \beta$-glucanase, CelA4, from thermoacidophilic Alicyclobacillus sp. A4. Herein, we described the gene sequence and the expression of $\mathrm{CelA}_{F}$, which encodes CelA4 lacking the $\mathrm{N}$-terminal signal sequence. Its deduced amino acid sequence is only $42 \%$ identical to that of CelB from $A$. acidocaldarius [6], indicating that CelA4 is a previously uncharacterized gene. The deduced C-terminal 217-residue sequence of CelA4 is threonine rich (21.2\%), which is a much higher than found on average $(5.74 \%)$ for proteins [17]. Threonine-rich regions have been reported to be involved in fibronectin binding [18], unidirectional transport of a mineralocorticoid receptor into the nucleus [19], vanadate resistance [20], and resistance to HIV by binding to a specific receptor [21]. Structural analysis has indicated that the functions of threonine-rich regions are usually associated with those of linker regions and $\mathrm{O}$ linked glycosylation $[22,23]$. We have found that the threonine-rich region containing the putative linker of native CelA4 and CelA4 $4_{F}$ was removed during secretion from Alicyclobacillus sp. A4 and P. pastoris, respectively. Therefore, the threonine-rich region may act as a molecular chaperone and be involved in proper folding of the catalytic domain. The linker has been reported to be necessary for thermostability $[24,25]$. Because it is removed with the threonine-rich sequence, we assume that the linker has no effect on the catalytic properties of CelA4.

Native CelA4 has excellent properties and therefore has great potential for use in industrial applications [7]. However, the yield of CelA4 was very small $(0.9 \mathrm{U} / \mathrm{mL})$ when Alicyclobacillus sp. A4 was cultured in a glucanase-inducing medium. For the study reported herein, we used a 3.7$\mathrm{L}$ fermenter for the cultivation of $P$. pastoris containing a plasmid carrying CelA $4_{F}$. After expression, $268 \mathrm{U} / \mathrm{mL}$ of CelA4 activity was measured in the culture supernatant, which is approximately 300 -fold greater than found upon cultivation of Alicyclobacillus sp. A4. We also constructed a gene for the C-terminally truncated glucanase, CelA4 $4_{\mathrm{T}}$ that lacked the threonine-rich region using a PCR-based gene truncation method, expressed the protein in P. pastoris, and obtained a yield of $420 \mathrm{U} / \mathrm{mL}$. Expression of truncated genes has been shown to increase enzyme production and improve both activity and thermostability $[26,27]$. Truncated CelA4 $4_{F}$ and artificially truncated 


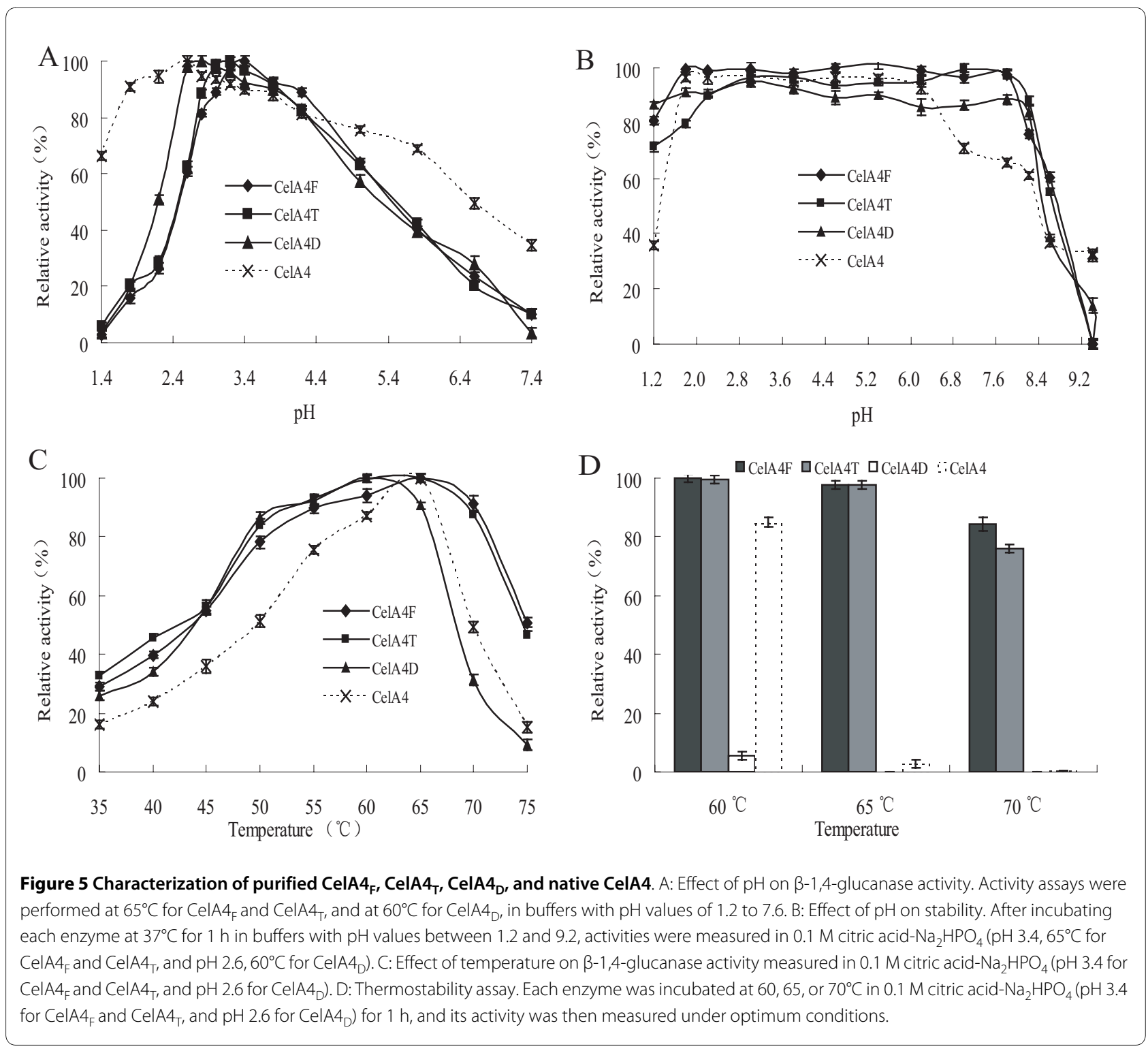

CelA4 $4_{\mathrm{T}}$ have similar molecular masses and enzymatic properties but differ in the relative amount of enzyme produced by fermentation. This difference might be ascribed to the intracellular functions of the threoninerich region. It is possible that the threonine-rich region acts as a molecular chaperone, but how it influences enzyme production is unknown.

Both $\mathrm{CelA}_{\mathrm{F}}$ and $\mathrm{CelA}_{\mathrm{T}}$ were glycosylated when expressed in P. pastries. It has been reported that glycosylation has significant effects on enzyme thermostability [28], the optimum $\mathrm{pH}$ value [29], and resistance to proteases [30,31]. CelA4 ${ }_{\mathrm{D}}, \mathrm{CelA} 4_{\mathrm{F}}$, and CelA4 ${ }_{\mathrm{T}}$ had similar $\mathrm{pH}$ and stability profiles, but CelA4 ${ }_{\mathrm{D}}$ was not as thermally stable as the other two proteins. For example, CelA4 ${ }_{D}$ exhibited $\sim 30 \%$ of its maximal activity at $70^{\circ} \mathrm{C}$, whereas both CelA $4_{\mathrm{F}}$ and $\mathrm{CelA} 4_{\mathrm{T}}$ retained $\sim 90 \%$ of their initial activities. Moreover, CelA4 $4_{\mathrm{F}}$ and CelA4 $4_{\mathrm{T}}$ were thermostable at $70^{\circ} \mathrm{C}$, but CelA $4_{\mathrm{D}}$ was not stable at $60^{\circ} \mathrm{C}$. Although the molecular mass of CelA $4_{D}$ was similar to that of native CelA4, these enzymes differed with respect to their $\mathrm{pH}$ and temperature profiles and, most notably, their stabilities. Therefore, heterologous expression of CelA4 $4_{\mathrm{F}}$ increased the amount of the enzyme produced and improved the thermostability by incorporating sugar residues post-translationally.

CelA4 ${ }_{\mathrm{T}}$ and CelA4 ${ }_{\mathrm{F}}$ exhibited similar enzymatic properties, namely a pH optimum of 3.4 , a temperature optimum of $65^{\circ} \mathrm{C}$, stability between $\mathrm{pH} 2.0$ and 8.2 and at $70^{\circ} \mathrm{C}$, and they were both active and stabile under simulated gastric conditions. Both enzymes could decrease 
the viscosity of barley-soybean feed (data not shown), but more of the former was produced during P. pastoris fermentation. Therefore, in the future we will produce CelA $4_{\mathrm{T}}$, not CelA4 $\mathrm{F}$, by heterologous expression for commercial applications.

\section{Conclusions}

For the study reported herein, we identified and cloned the $\beta$-1,4-glucanase-encoding gene (CelA4) found in Alicyclobacillus sp. A4, and achieved high-yield expression of CelA4 ${ }_{\mathrm{F}}$ in P. pastoris. CelA4 ${ }_{\mathrm{F}}$ was truncated and glycosylated during fermentation. Expression of CelA $4_{\mathrm{T}}$, which lacks the threonine-rich region, produced greater amounts of protein and had glucanase activity identical to that of CelA4 $4_{\mathrm{F}}$. We speculate that the threonine-rich region might act as a molecular chaperone that ensures proper folding of the catalytic domain. Glycosylation was necessary for the thermostability of both CelA4 $4_{F}$ and CelA4 $4_{\mathrm{T}}$. All of our data indicate that recombinant CelA4 $4_{\mathrm{T}}$ produced using a $P$. pastoris fermentation system will have great potential as a $\beta$-1,4-glucanase for use in the feed industry.

\section{Methods}

\section{Strains, plasmids, and chemicals}

The strain Alicyclobacillus sp. A4 was deposited in the China General Microbiological Culture Collection Center under the registration number CGMCC3147 [32]. Escherichia coli JM109 was obtained from TaKaRa (Dalian, China). P. pastoris GS115 and the pPIC9 vector were obtained from Invitrogen (San Diego, CA, USA). Barley $\beta$-glucan was supplied by Sigma (St. Louis, MO, USA). T4 DNA ligase and restriction endonucleases were obtained from Promega (Madison, WI, USA). All other chemicals were of analytical grade and commercially available.

\section{Cloning and expression of the $\beta-1,4$-glucanase gene $\left(\right.$ CelA4 $\left.{ }_{\mathrm{F}}\right)$}

Using the sequences of an $\mathrm{N}$-terminal peptide and five internal peptides of native CelA4 [7], the full-length coding gene for CelA4 (CelA4) was identified in the genome of Alicyclobacillus sp. A4 using BLASTp (Sequencing of the complete Alicyclobacillus sp. A4 genome is in progress). The sequence of the $\mathrm{N}$-terminal signal peptide was predicted using SignalP http://www.cbs.dtu.dk/services/ SignalP/. Alignment of multiple protein sequences was accomplished using ClustalW [33]. Vector NTI 10.0 software was used to identify homologous and identical residues after sequence alignment and to predict the molecular mass of the mature protein.

To construct the plasmid containing $\mathrm{CelA}_{F}$, the gene encoding CelA4 $4_{\mathrm{F}}$ was $\mathrm{PCR}$-amplified using the primers
CelA4 ${ }_{\mathrm{F}} \mathrm{F}:$ GCATACGTAATGGAGGCGACTATGCAA GCAGC and CelA4 ${ }_{\mathrm{F}} \mathrm{R}$ : GAAGCGGCCGCTCAGACACCCACAAAATGAGAAACCAC (SnaBI and Not I sites are bold) with Alicyclobacillus sp. A4 genomic DNA as the template. The PCR-amplified gene fragment was cloned in-frame at the downstream site of the $\alpha$-factor (signal peptide) present in the pPIC9 vector and transformed into $P$. pastoris competent cells. Positive transformants were cultured in minimal dextrose medium or minimal methanol medium, and the culture supernatants were screened for glucanase activity.

\section{High-cell-density fermentation of recombinant CelA4 $F$}

The positive transformant with the highest level of $\beta-1,4$ glucanase activity was grown in a 3.7-L fermenter (Bioengineering KLF 2000, Wald, Switzerland) using a four-step fermentation strategy [13] that was scaled up. The Pichia fermentation was performed according to instructions obtained from Invitrogen. Fermentation began with a batch growth phase in 2.0-L basic sodium medium and the following conditions were used: agitation speed, 1,000 $\mathrm{rpm}$; ventilation rate, $1.6 \mathrm{vvm}$; temperature, $30^{\circ} \mathrm{C} ; \mathrm{pH}, 4.5$ (adjusted with $6 \mathrm{M} \mathrm{NH}_{4} \mathrm{OH}$ ). The first phase was terminated when the glycerol in the basic sodium medium was consumed completely (about $18 \mathrm{~h}$ ) and the cell mass had increased to $>100 \mathrm{~g} / \mathrm{L}$ (wet cell weight). The second glycerol $(50 \%, \mathrm{w} / \mathrm{v})$ fed-batch phase was initiated at $70 \mathrm{~mL} / \mathrm{h}$ for $\sim 6 \mathrm{~h}$ to further increase the cell mass to $\sim 170 \mathrm{~g} / \mathrm{L}$. During the third phrase, a glycerol/methanol (8:1, v:v) mixture was fed at $25 \mathrm{~mL} / \mathrm{h}$ for $\sim 4 \mathrm{~h}$ to transition the culture from glycerol to methanol. In the fourth phase, methanol was fed at 6-7 mL/h for $\sim 156 \mathrm{~h}$. During the fermentation process, dissolved oxygen was kept above $20 \%$. Culture samples were collected every $12 \mathrm{~h}$ and subjected to cell mass and enzyme activity analyses.

\section{Purification and identification of recombinant CelA4}

The culture supernatant (about 2,500 mL) was concentrated $\sim 15$-fold by ultrafiltration using hollow-fiber membranes with molecular weight cut-offs of first $6 \mathrm{kDa}$ (Motimo, Tianjin, China) and then $5 \mathrm{kDa}$ (Vivascience, Hannover, Germany). The resulting solution was dialyzed against $20 \mathrm{mM}$ McIlvaine buffer $\left(0.2 \mathrm{M} \mathrm{Na}_{2} \mathrm{HPO}_{4}\right.$ containing $0.1 \mathrm{M}$ citric acid), $\mathrm{pH} 7.5$, and loaded onto a HiTrap Q Sepharose XL FPLC column (Amersham Pharmacia Biotech, Uppsala, Sweden) equilibrated with the same buffer. Proteins were eluted using a linear gradient of $\mathrm{NaCl}(0-1.0 \mathrm{M})$ in the same buffer. Fractions with enzyme activity were collected and subjected to SDSPAGE [34]. To identify the purified protein as CelA4 $4_{F}$, the protein band was excised from the gel, digested with trypsin, and sequenced using liquid chromatography/ electrospray ionization tandem mass spectrometry 
(MALDI-TOF-MS/MS) at the Institute of Zoology, Chinese Academy of Sciences.

\section{Cloning of the artificially truncated $\beta$-1,4-glucanase gene (CelA4 $\left.{ }_{T}\right)$}

According to the molecular mass comparison of CelA4 ${ }_{\mathrm{F}}$ and native CelA4 and the sequence analysis, residues 498-715 was supposed to be hit by profiles with a high probability of occurrence (Entry: PS50325) based on ScanProsite analysis http://www.expasy.ch/tools/scanprosite. Residue 497 was predicted to be the truncation site. CelA4 $4_{T}$ encoding the truncated protein (residues 40497) was PCR-amplified using the primers $\mathrm{CelA} 4_{\mathrm{T}} \mathrm{F}$ (GCATACGTAATGGAGGCGACTATGCAAGCAGC) and CelA4 ${ }_{\mathrm{T}}$ R (GAAGCGGCCGCAAACTGTGGCCCTTGTGGCTGATGC) (SnaBI and NotI sites are bold) with genomic DNA of Alicyclobacillus sp. A4 as the template. $\mathrm{CelA}_{\mathrm{T}}$ was expressed in P. pastoris and subjected to the same purification procedure as described above.

\section{Deglycosylation of CelA4}

Purified CelA $4_{\mathrm{F}}(\mathrm{a} \sim 2 \mu \mathrm{g})$ was treated with $20 \mathrm{U}$ of Endo $\mathrm{H}$ for $2 \mathrm{~h}$ at $37^{\circ} \mathrm{C}$ according to the supplier's instructions (New England Biolabs, Ipswich, MA, USA) and then analyzed by SDS-PAGE.

\section{Enzyme assay}

All enzymatic assays were performed in triplicate. The final reaction systems contained $50 \mu \mathrm{L}$ of an appropriately diluted enzyme and a $450-\mu \mathrm{L}$ solution containing $1 \%$ barley $\beta$-glucan (w/v) and $200 \mathrm{mM}$ Mcllvaine buffer at the optimum $\mathrm{pH}$ previously determined for each enzyme. Reactions were allowed to proceed for $10 \mathrm{~min}$ at the optimum temperatures and then terminated by adding 1.5 $\mathrm{mL}$ dinitrosalicylic acid [35]. Each mixture was heated in a boiling water bath for $5 \mathrm{~min}$. After addition of $1.0 \mathrm{~mL}$ $\mathrm{H}_{2} \mathrm{O}$, the absorbance of each mixture at $540 \mathrm{~nm}$ was measured. One unit of enzyme activity was defined as the amount of enzyme that catalyzed the formation of $1 \mu \mathrm{mol}$ glucose per minute.

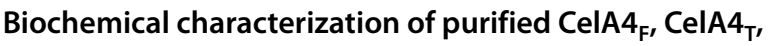 and CelA4}

The $\mathrm{pH}$ optima for the enzyme activities of $\mathrm{CelA} 4_{\mathrm{F}}$ and CelA4 $4_{\mathrm{T}}$ were determined at $65^{\circ} \mathrm{C}$ and at $60^{\circ} \mathrm{C}$ for CelA4 $4_{\mathrm{D}}$. The enzymes were incubated for $1 \mathrm{~h}$ at $37^{\circ} \mathrm{C}$ in the absence of substrate, and then their activities were measured at $\mathrm{pH} 3.4$ and $65^{\circ} \mathrm{C}$ for CelA $4_{\mathrm{F}}$ and CelA $4_{\mathrm{T}}$, and at $\mathrm{pH} 2.6$ and $60^{\circ} \mathrm{C}$ for CelA4 ${ }_{\mathrm{D}}$. The buffers used were $0.1 \mathrm{M}$ $\mathrm{KCl}-\mathrm{HCl}$ for $\mathrm{pH} 1.2-2.2,0.1 \mathrm{M}$ Mcllvaine buffer for $\mathrm{pH}$ 2.6-7.6, 0.1 M Tris- $\mathrm{HCl}$ for $\mathrm{pH}$ 8.0-9.0, and 0.1 M glycine$\mathrm{NaOH}$ for $\mathrm{pH}$ 9.4-12.0. The optimal temperature for enzyme activity was determined using the Mcllvaine buf- fer (pH 3.4 for CelA4 $4_{\mathrm{F}}$ and CelA4 $4_{\mathrm{T}} ; \mathrm{pH} 2.6$ for CelA4 $4_{\mathrm{D}}$ ) at temperatures between $35^{\circ} \mathrm{C}$ and $75^{\circ} \mathrm{C}$. The thermostability of each enzyme was determined by incubating the enzyme $(100 \mu \mathrm{g} / \mathrm{mL})$ in McIlvaine buffer $(\mathrm{pH} 3.4$ for CelA4 ${ }_{\mathrm{F}}$ and CelA4 $4_{\mathrm{T}} ; \mathrm{pH} 2.6$, for CelA4 ${ }_{\mathrm{D}}$ ) at $60^{\circ} \mathrm{C}, 65^{\circ} \mathrm{C}$, or $70^{\circ} \mathrm{C}$ without substrate for $1 \mathrm{~h}$ and then measuring the enzyme activity under optimum conditions.

To examine resistance to different proteases, purified $\mathrm{CelA}_{\mathrm{F}}, \mathrm{CelA}_{\mathrm{T}}$, and CelA4 $4_{\mathrm{D}}(2 \mu \mathrm{g} / \mathrm{mL})$ were each incubated with $200 \mu \mathrm{g} / \mathrm{mL}$ trypsin, $\alpha$-chymotrypsin, collagenase, pepsin, or $500 \mu \mathrm{g} / \mathrm{mL}$ subtilisin $\mathrm{A}$ at $37^{\circ} \mathrm{C}$ and at the $\mathrm{pH}$ optimum of the specific protease for various lengths of time. Incubations in the absence of each protease served as the controls. Activities were determined under the standard assay conditions of $\mathrm{pH} 3.4,65^{\circ} \mathrm{C}$ for $\mathrm{CelA} 4_{\mathrm{F}}$ and CelA $4_{\mathrm{T}}$, and of $\mathrm{pH} 2.6,60^{\circ} \mathrm{C}$ for CelA4 ${ }_{\mathrm{D}}$.

\section{Abbreviations}

Endo $\mathrm{H}$ : endo- $\beta$ - $N$-acetylglucosaminidase H; SDS-PAGE: sodium dodecyl sulfate-polyacrylamide gel electrophoresis.

\section{Competing interests}

The authors declare that they have no competing interests.

\section{Authors' contributions}

YB participated in the design of the study, the fermentation development, data analysis, and in the writing of the manuscript. JW participated in the construction of the recombinant plasmids. CL participated in the fermentation procedures and data analysis. YF participated in the biochemical characterization of the enzymes. ZZ participated in the writing and reviewing of the manuscript. BY participated in the writing and editorial supervision of the manuscript. PS supervised the experiments. $\mathrm{HH}$ participated in the gene sequence analysis. $\mathrm{HL}$ participated in the result analysis and the writing of the manuscript. All authors read and approved the final manuscript.

\section{Acknowledgements}

This research was supported by the National High Technology Research and Development Program of China (863 program, grant 2007AA100601) and the earmarked fund for modern agro-industry technology research system (NYCYTX-42-G2-05).

\section{Author Details}

1Key Laboratory for Feed Biotechnology of the Ministry of Agriculture, Feed Research Institute, Chinese Academy of Agricultural Sciences, Beijing 100081, PR China and ${ }^{2}$ Biotechnology Research Institute, Chinese Academy of Agricultural Sciences, Beijing 100081, PR China

\section{Received: 12 March 2010 Accepted: 14 May 2010}

Published: 14 May 2010

\section{References}

1. Lee C, Horsley R, Manthey F, Schwarz P: Comparisons of $\beta$-glucan content of barley and oat. Cereal Chemistry 1997, 74:571-575.

2. Liu B, Yang Q, Zhou Q, Song J, Chen D, Liu H: Cloning and expression of the endo- $\beta$-glucanase III cDNA gene from Trichoderma viride AS3.3711. Acta Environment Sinica 2004, 25:127-132.

3. Celestino KR, Cunha RB, Felix CR: Characterization of a $\beta$-glucanase produced by Rhizopus microsporus var. microsporus, and its potential for application in the brewing industry. BMC Biochemistry 2006, 7:23.

4. Walsh GA, Murphy RA, Killeen GF, Headon DR, Power RF: Technical note: detection and quantification of supplemental fungal $\beta$-glucanase activity in animal feed. Journal of Animal Science 1995, 73:1074-1076.

5. Eckert K, Zielinski F, Lo Leggio L, Schneider E: Gene cloning, sequencing, and characterization of a family 9 endoglucanase (CelA) with an unusual pattern of activity from the thermoacidophile Alicyclobacillus 
acidocaldarius ATCC27009. Applied Microbiology and Biotechnology 2002, 60:428-436.

6. Eckert K, Schneider E: A thermoacidophilic endoglucanase (CelB) from Alicyclobacillus acidocaldarius displays high sequence similarity to arabinofuranosidases belonging to family 51 of glycoside hydrolases. European Journal of Biochemistry 2003, 270:3593-3602.

7. Bai Y, Wang J, Zhang Z, Shi P, Luo H, Huang H, Feng Y, Yao B: Extremely acidic $\beta-1,4$-glucanase, CelA4, from thermoacidophilic Alicyclobacillus $\mathrm{sp}$. A4 with high protease resistance and potential as a pig feed additive. Journal of Agriculture and Food Chemistry 2010, 58:1970-1975.

8. Bai Y, Wang J, Zhang Z, Shi P, Luo H, Huang H, Luo C, Yao B: A novel family $9 \beta-1,3(4)$-glucanase from thermoacidophilic Alicyclobacillus sp. A4 with potential applications in the brewing industry. Applied Microbiology and Biotechnology 2010. DOI: 10.1007/s00253-010-2452-3

9. Morana A, Esposito A, Maurelli L, Ruggiero G, lonata E, Rossi M, La Cara F: A novel thermoacidophilic cellulase from Alicyclobacillus acidocaldarius. Protein and Peptide Letter 2008, 15:1017-1021.

10. Malburg SR, Malburg LM Jr, Liu T, lyo AH, Forsberg CW: Catalytic properties of the cellulose-binding endoglucanase $F$ from Fibrobacter succinogenes S85. Applied Environment and Microbiology 1997, 63:2449-2453

11. Grant S, Sorokin DY, Grant WD, Jones BE, Heaphy S: A phylogenetic analysis of Wadi el Natrun soda lake cellulase enrichment cultures and identification of cellulase genes from these cultures. Extremophiles 2004, 8:421-429.

12. Sreekrishna K, Brankamp RG, Kropp KE, Blankenship DT, Tsay JT, Smith PL, Wierschke JD, Subramaniam A, Birkenberger LA: Strategies for optimal synthesis and secretion of heterologous proteins in the methylotrophic yeast Pichia pastoris. Gene 1997, 190:55-62.

13. Plantz BA, Sinha J, Villarete L, Nickerson KW, Schlegel VL: Pichia pastoris fermentation optimization: energy state and testing a growthassociated model. Applied Microbiology and Biotechnology 2006, 72:297-305.

14. Wootton JC, Federhen S: Analysis of compositionally biased regions in sequence databases. Methods in Enzymology 1996, 266:554-571.

15. Shallom D, Belakhov V, Solomon D, Gilead-Gropper S, Baasov T, Shoham $G$, Shoham $Y$ : The identification of the acid-base catalyst of aarabinofuranosidase from Geobacillus stearothermophilus T-6, a family 51 glycoside hydrolase. FEBS Letter 2002, 514:163-167.

16. Gilkes NR, Henrissat B, Kilburn DG, Miller RC Jr, Warren RA: Domains in microbial $\beta-1,4$-glycanases: sequence conservation, function, and enzyme families. Microbiological Reviews 1991, 55:303-315.

17. Karlin S, Bucher P, Brendel V, Altschul SF: Statistical methods and insights for protein and DNA sequences. Annual Review of Biophysics and Biophysical Chemistry 1991, 20:175-203.

18. Rauceo JM, De Armond R, Otoo H, Kahn PC, Klotz SA, Gaur NK, Lipke PN: Threonine-rich repeats increase fibronectin binding in the Candida albicans adhesin Als5p. Eukaryotic Cell 2006, 5:1664-1673.

19. Walther RF, Atlas E, Carrigan A, Rouleau Y, Edgecombe A, Visentin L, Lamprecht C, Addicks GC, Hache RJ, Lefebvre YA: A serine/threonine-rich motif is one of three nuclear localization signals that determine unidirectional transport of the mineralocorticoid receptor to the nucleus. Journal of Biological Chemistry 2005, 280:17549-17561.

20. Nakamura T, Namba H, Ohmoto T, Liu Y, Hirata D, Miyakawa T: Cloning and characterization of the Saccharomyces cerevisiae SVS1 gene which encodes a serine- and threonine-rich protein required for vanadate resistance. Gene 1995, 165:25-29.

21. Cotelle N, Lohez M, Cotelle P, Henichart JP: Conformational study of the threonine-rich C-terminal pentapeptide of peptide T. Biochemistry and Biophysics Research Communication 1990, 171:596-602.

22. Tyshenko M, d'Anjou M, Davies P, Daugulis A, Walker V: Challenges in the expression of disulfide bonded, threonine-rich antifreeze proteins in bacteria and yeast. Protein Expression and Purification 2006, 47:152-161.

23. Kieliszewski MJ, Leykam JF, Lamport DT: Structure of the Threonine-Rich Extensin from Zea mays. Plant Physiology 1990, 92:316-326.

24. Dias FM, Goyal A, Gilbert HJ, Jose AMP, Ferreira LM, Fontes CM: The Nterminal family 22 carbohydrate-binding module of xylanase $10 \mathrm{~B}$ of Clostridium themocellum is not a thermostabilizing domain. FEMS Microbiology Letters 2004, 238:71-78.

25. Li N, Shi P, Yang P, Wang Y, Luo H, Bai Y, Zhou Z, Yao B: A xylanase with high pH stability from Streptomyces sp. S27 and its carbohydrate- binding module with/without linker-region-truncated versions. Applied Microbiology and Biotechnology 2008, 83:99-107.

26. Paloheimo M, Mantyla A, Kallio J, Puranen T, Suominen P: Increased production of xylanase by expression of a truncated version of the xyn11A gene from Nonomuraea flexuosa in Trichoderma reesei. Applied Environment and Microbiology 2007, 73:3215-3224.

27. Wen TN, Chen JL, Lee SH, Yang NS, Shyur LF: A truncated Fibrobacter succinogenes 1,3-1,4- $\beta$-D-glucanase with improved enzymatic activity and thermotolerance. Biochemistry 2005, 44:9197-9205.

28. Clark SE, Muslin EH, Henson CA: Effect of adding and removing Nglycosylation recognition sites on the thermostability of barley aglucosidase. Protein Engineering, Design and Selection 2004, 17:245-249.

29. Somera AF, Pereira MG, Souza Guimaraes LH, Polizeli Mde L, Terenzi HF, Melo Furriel RP, Jorge JA: Effect of glycosylation on the biochemical properties of $\beta$-xylosidases from Aspergillus versicolor. Journal of Microbiology 2009, 47:270-276

30. Wyss M, Pasamontes L, Friedlein A, Remy R, Tessier M, Kronenberger A, Middendorf A, Lehmann M, Schnoebelen L, Rothlisberger U, et al: Biophysical characterization of fungal phytases (myo-inositol hexakisphosphate phosphohydrolases): molecular size, glycosylation pattern, and engineering of proteolytic resistance. Applied Environment and Microbiology 1999, 65:359-366.

31. Takegawa K, Yoshikawa M, Mishima T, Nakoshi M, Iwahara S: Determination of glycosylation sites using a protein sequencer and deglycosylation of native yeast invertase by endo- $\beta-N-$ acetylglucosaminidase. Biochemistry International 1991, 25:585-592.

32. Bai Y, Wang J, Zhang Z, Yang P, Shi P, Luo H, Meng K, Huang H, Yao B: A new xylanase from thermoacidophilic Alicyclobacillus sp. A4 with broad-range $\mathrm{pH}$ activity and $\mathrm{pH}$ stability. Journal of Industrial Microbiology and Biotechnology 2010, 37:187-194.

33. Thompson JD, Higgins DG, Gibson TJ: CLUSTAL W: improving the sensitivity of progressive multiple sequence alignment through sequence weighting, position-specific gap penalties and weight matrix choice. Nucleic Acids Research 1994, 22:4673-4680

34. Laemmli UK: Cleavage of structural proteins during the assembly of the head of bacteriophage T4. Nature 1970, 227:680-685.

35. Miller GL: Use of dinitrosalicylic acid reagent for determination of reducing sugar. Analytical Chemistry 1959, 31:426-428.

doi: 10.1186/1475-2859-9-33

Cite this article as: Bai et al., Expression of an extremely acidic ?-1,4-glucanase from thermoacidophilic Alicyclobacillus sp. A4 in Pichia pastoris is improved by truncating the gene sequence Microbial Cell Factories 2010, 9:33

\section{Submit your next manuscript to BioMed Centra and take full advantage of:}

- Convenient online submission

- Thorough peer review

- No space constraints or color figure charges

- Immediate publication on acceptance

- Inclusion in PubMed, CAS, Scopus and Google Scholar

- Research which is freely available for redistribution
C Biomed Central 